\title{
Interactions between Angiotensin Peptides and the Sympathetic Nervous System Mediating Intestinal Sodium and Water Absorption in the Rat
}

\author{
Nigel R. Levens, Michael J. Peach, and Robert M. Carey, \\ Division and Endocrinology and Metabolism, Department of Internal Medicine, \\ and the Department of Pharmacology, University of Virginia School of Medicine, \\ Charlottesville, Virginia 22908
}

\begin{abstract}
A B S T R A C T The purpose of this study was to determine the locus of interaction of angiotensin peptides with the sympathetic nervous system leading to alterations in jejunal sodium and water transport. At low physiological doses, angiotensin II (AII) stimulates jejunal sodium and water absorption, while at high doses peptide inhibits absorption and/or stimulates secretion. Both the stimulation of jejunal transport and the inhibition of absorption were expressed in adrenalectomized rats. However, the stimulation of jejunal water absorption was abolished and a potentiated inhibition of transport was expressed in peripherally sympathectomized rats (intact adrenal medulla) and in normal rats after administration of guanethadine, phentolamine, and prazosin. The angiotensin analog ( Sar $^{1}$ Leu $^{8}$ )-AII has low efficacy and is a potent competitive antagonist of the parent peptide in pressor and myotropic systems, but is a full agonist with even greater potency than AII in stimulating jejunal transport. The increased water transport in response to $\left(\mathrm{Sar}^{1} \mathrm{Leu}^{8}\right)$-AII is not secondary to enhanced renal renin release, as the analog also stimulated jejunal transport in the presence of captopril and after bilateral nephrectomy. The stimulation of absorption in response to $\left(\mathrm{Sar}^{1} \mathrm{Leu}^{8}\right)$-AII alone or together with AII was abolished by phentolamine.
\end{abstract}

These data demonstrate that AII-increased intestinal absorption is secondary to the release of norepinephrine from nerve endings in the jejunum and that AII inhibition of absorption is not mediated by the sympathetic nervous system. The analog $\left(\mathrm{Sar}^{1} \mathrm{Leu}^{8}\right)$-AII is

Dr. Carey is an Established Investigator of the American Heart Association. Dr. Levens is a recipient of a Postdoctoral Travel Award from the Wellcome Trust, England. Address reprint requests to Dr. Levens.

Received for publication 22 September 1980 and in revised form 25 November 1980. a full agonist in the stimulation of jejunal transport (increased norepinephrine release), but antagonizes the inhibitory response to high doses of AII. Angiotensin peptides are potent modulators of intestinal sodium and water absorption.

\section{INTRODUCTION}

The octapeptide hormone angiotensin II is a physiologically important sodium-retaining hormone, contributing to the maintenance of extracellular fluid volume by stimulating thirst (1), aldosterone production (2), vasopressin release (3), and transport of sodium and water across epithelial tissues (1-7). The effects of angiotensin II on transporting epithelia are concentration dependent. In the isolated and in situ kidney $(4,5)$ or the isolated intestine or jejunum in vivo $(6,7)$, low physiological concentrations of angiotensin II stimulate net mucosal to serosal transfer of sodium and water, whereas high concentrations of the hormone inhibit transport and/or stimulate secretion. Changes in intestinal blood flow are not responsible for the effects of the hormone on transport in vivo (7). The fact that angiotensin II is effective in vitro suggests that angiotensin II exerts a direct action on the transporting cells of the intestine. However, meclofenamate and indomethacin abolish the inhibition of intestinal absorption (or secretion) produced by angiotensin II, suggesting that at high doses the hormone acts by stimulating intestinal prostaglandin production (8).

Previous studies have shown that stimulation of sodium and water absorption in response to low doses of angiotensin II can be abolished by $\alpha$-adrenergic receptor antagonists (phentolamine and dihydroergotamine) and by pretreatment with reserpine, but not by the $\beta$-adrenergic receptor antagonist, propranolol (9). It is possible, then, that the enhanced intestinal absorp- 
tion of sodium and water in response to angiotensin II is mediated by an $\alpha$-adrenergic event. However, angiotensin II interacts with the sympathetic nervous system both by facilitating release of norepinephrine from nerve endings and by stimulating secretion of adrenal catecholamines (10). Furthermore, phentolamine and dihydroergotamine block both pre- and postsynaptic $\alpha$-adrenergic receptors (10). Therefore, the exact locus of the interaction of angiotensin II with the sympathoadrenal system is unknown.

Analogs of angiotensin II, substituted at the $\mathrm{NH}_{2}$ terminus with a sarcosyl residue and at the $\mathrm{COOH}$ terminus with a variety of aliphatic amino acids, are potent competitive antagonists of the parent peptide in many tissues that respond to angiotensins (11). In contrast, these peptide derivatives of angiotensin II are equipotent with or have even greater potency than the parent peptide in stimulating intestinal sodium and water transport and are devoid of an inhibitory (secretory) response (12). However, infusion of peptide inhibitors of angiotensin II in-vivo increases plasma renin activity by blocking the negative feedback of angiotensin II on renal renin release (13). Therefore, the stimulation of transport in response to infusion of angiotensin antagonists may be mediated indirectly after release of renin with consequent increase in the systemic production of angiotensin II.

The purpose of the present study was to identify the specific locus of interaction of angiotensin II with the sympathoadrenal system in the control of intestinal sodium and water transport. In this study, we characterized the effect of an eight-substituted analog of angiotensin II ([Sar ${ }^{1}$ Leu $\left.^{8}\right]$-angiotensin II) on net jejunal sodium transport (measured as water absorption) in nephrectomized rats and also in normal rats in the presence of phentolamine and after pharmacological disruption of the renin-angiotensin system with the angiotensin converting enzyme inhibitor, captopril. We further determined the locus of action of angiotensin II on the sympathetic nervous system by demonstrating the effect of this peptide on jejunal sodium and water transport in peripherally sympathectomized rats (intact adrenal medulla), after adrenalectomy, and in the presence of phentolamine or the selective postsynaptic $\alpha$-adrenergic antagonist, prazosin.

\section{METHODS}

\section{Animals}

These experiments were conducted with male, albino Wistar rats weighing 250-400 g. Rats were maintained on a diet containing $100 \mathrm{meq}$ sodium $\mathrm{kg}$ chow, allowed free access to water, and housed in a room with a $12 \mathrm{~h}$ light cycle (6 a.m. to 6 p.m.). The animals were fasted overnight before use.

\section{Operative procedure}

After the induction of pentobarbital anesthesia (Nembutal sodium, Abbott Laboratories, North Chicago, Ill.) with 70 $\mathrm{mg} / \mathrm{kg}$ i.p., a polyethylene catheter $(1 \mathrm{~mm}$ o.d.) was inserted via the femoral vein into the inferior vena cava. This venous cannula was connected to a Harvard 975 infusion pump (Harvard Apparatus, Co., Inc., Millis, Mass.) through which isotonic saline with or without angiotensin I or II or a peptide analog was infused at the rate of $20 \mu \mathrm{l} / \mathrm{min}$.

\section{Measurement of jejunal water absorption}

A ventral midline celiotomy was performed and the proximal end of the jejunum loosely ligated, after which a second ligature was positioned and loosely tied $\sim 15 \mathrm{~cm}$ distal to the first. The resulting $15-\mathrm{cm}$ intestinal segment was washed thoroughly with isotonic saline, gently emptied, and the two ligatures were tightened to produce a closed jejunal sac.

After a 15-min rest period, the jejunal sac was filled with 3-4 ml Krebs bicarbonate buffer (14) containing $\left[{ }^{14} \mathrm{C}\right]-$ inulin $(20,000 \mathrm{dpm} / \mathrm{ml} ; 1.90 \mu \mathrm{Ci} / \mathrm{mg}$ sp act; New England Nuclear, Boston, Mass.), and a $0.15-\mathrm{ml}$ sample removed through a 27-gauge needle into a $1-\mathrm{ml}$ syringe. The sac was returned to the abdominal cavity and an intravenous infusion of isotonic saline was initiated $(20 \mu \mathrm{l} / \mathrm{min}) .15 \mathrm{~min}$ later, the jejunal sac was exposed and a second $0.15 \mathrm{ml}$ sample removed. The sac then was returned to the abdomen and the saline infusion either was continued (control animals) or was replaced by an infusion of angiotensin I, angiotensin II, or the peptide analog in saline that was delivered at $20 \mu \mathrm{l} / \mathrm{min}$ for an additional 15-min period (experimental animals). Since the venous cannula contained a $60 \mu \mathrm{l}$ dead space, the angiotensin II infusion for the second period was initiated $3 \mathrm{~min}$ before the second luminal sample was obtained so that the animals began receiving the angiotensin at the appropriate time.

At the completion of the peptide infusion, a final $0.15-\mathrm{ml}$ sample was obtained and the intestinal sac was removed from the animal and weighed. The segment of gut then was emptied and reweighed to obtain the volume of contents and the weight of the sac. In some experiments the intestinal sac was heated at $100^{\circ} \mathrm{C}$ for $24 \mathrm{~h}$ to obtain the dry weight of tissue. The exact volume of buffer injected into the sac and the volume of samples removed were obtained by weighing each on a Mettler microbalance (Mettler Instrument Corp., Highstown, N. J.). The luminal samples were transferred to $12 \times 75 \mathrm{~mm}$ centrifuge tubes and spun at $4,000 \mathrm{rpm}$ for 2 min to remove contaminating mucus. $50-\mu \mathrm{l}$ aliquots of each sample were assayed for $\left[{ }^{14} \mathrm{C}\right]$ inulin by liquid scintillation spectrometry.

Inulin was used as a nonabsorbable marker so that after the absorption of fluid from the sac, there was an increase in inulin concentration. From the volume of samples removed, water absorption from the jejunal segment during 2 consecutive 15 -min periods was calculated. Hence, each animal served as its own control.

A second procedure for assessing water transport was carried out routinely to confirm the measurement of water transport based on the radioactive inulin method. Water transport for the entire experimental period was calculated from the volume in the jejunal sac at 0 and $30 \mathrm{~min}$, with appropriate corrections for the aliquots removed from the intestinal sac. Experiments in which a significant difference existed between transport measured by the radioactive marker method and transport measured by the weight method were discarded. The validity of this preparation for the measurement of net intestinal ion transport (measured as 
water absorption) has been studied extensively by Levens (15) and Bolton et al. (7).

\section{Calculations}

Calculation a. Measurement of intestinal water transport using radiolabeled inulin. $\mathrm{V}_{1}=$ volume of fluid injected into the sac at $0 \mathrm{~min} . \mathrm{V}_{2}=$ volume of first sample, removed at $0 \mathrm{~min} . \mathrm{V}_{3}=$ volume of second sample, removed at $15 \mathrm{~min}$. Volume of fluid transported in the first period is represented by:

$$
\left(V_{1}-V_{2}\right)-\left[\left(V_{1}-V_{2}\right) \cdot \frac{d p m 0 \text { min }}{d p m 15 \text { min }}\right]=X
$$

Volume of fluid transported in the second period is represented by:

$$
\begin{aligned}
\left(V_{1}-V_{2}\right)-(X & \left.+V_{3}\right) \\
& -\left[\left[\left(V_{1}-V_{2}\right)-\left(X+V_{3}\right)\right] \cdot \frac{d p m 15 \text { min }}{d p m ~ 30 \text { min }}\right]=Y .
\end{aligned}
$$

The volumes of fluid transported in each period ( $\mathrm{X}$ and $\mathrm{Y}$ ) were divided by the wet weight of the sac removed from the animal.

Calculation $b$. Measurement of intestinal water transport by weight. $W_{1}=$ volume of fluid injected into the sac at 0 min. $W_{2}, W_{3}, W_{4}=$ volume of fluid removed from the sac at 0,15 , $30 \mathrm{~min} . \mathrm{W}_{5}=$ volume of fluid remaining in the sac at $30 \mathrm{~min}$. $\mathrm{W}_{6}=$ wet weight of the sac. Volume of fluid transported during the experimental period is represented by: $W_{1^{-}}$ $\left(\mathrm{W}_{2}+\mathrm{W}_{3}+\mathrm{W}_{4}+\mathrm{W}_{5}\right) / \mathrm{W}_{6}$.

Production of peripheral sympathectomy. Newborn rats were sympathectomized by the method described by Johnson et al. (16). 1 wk after birth, the rats received a single daily subcutaneous injection of $50 \mathrm{mg} / \mathrm{kg}$ guanethidine sulphate (Ciba-Giegy Corp., Summit, N. J.) administered in 100 $\mu \mathrm{l}$ of isotonic saline ( $\mathrm{pH} 7.0-7.5) 5 \mathrm{~d} / \mathrm{wk}$ for $3 \mathrm{wk}$. Sympathectomized rats exhibited similar growth curves to untreated Wistar controls. The effect of angiotensin on jejunal water transport was studied when the animals had reached 250$400 \mathrm{~g}, \sim 6-10 \mathrm{wk}$ after receiving the last dose of guanethidine. Verification of peripheral sympathectomy was determined by catecholamine analysis of the hearts as described below.

\section{Adrenalectomy and nephrectomy}

Bilateral adrenalectomy was performed under ether anesthesia $24 \mathrm{~h}$ before the measurement of water transport. Bilateral nephrectomy was performed under barbiturate anesthesia (Nembutal Sodium, $70 \mathrm{mg} / \mathrm{kg}$ i.p.) $3 \mathrm{~h}$ before the measurement of water transport.

\section{Determination of plasma converting enzyme activity}

Plasma converting enzyme activity was determined by radioassay from a modification of the method of Cushman and Cheung (17) using commercially available reagents (Ventrex Laboratories, Portland, Maine). In this method, diluted plasma is incubated with a radiolabeled acylated tripeptide $\left[{ }^{3} \mathrm{H}\right] \mathrm{Hip}-\mathrm{Gly}-\mathrm{Gly}$ and enzyme activity calculated from the quantity of $\left[{ }^{3} \mathrm{H}\right]$ hippuric acid that partitions from the reaction mixture into ethyl acetate.

\section{Determination of plasma renin activity}

Plasma renin activity was determined by radioimmunoassay from a modification of the method of Haber et al. (18).
In this method, duplicate $100 \mu \mathrm{l}$ samples of plasma anticoagulated with $1 \mathrm{mg} / \mathrm{ml}$ EDTA were incubated at $37^{\circ} \mathrm{C}$ for $2 \mathrm{~h}$ and the angiotensin $\mathrm{I}$ generated was estimated by radioimmunoassay.

\section{Catecholamine analysis}

Hearts were removed from untreated and sympathectomized rats, washed in iced saline, damp blotted, and weighed. The hearts were minced and homogenized in 5\% trichloroacetic acid at $4^{\circ} \mathrm{C}(1: 10 \mathrm{wt} / \mathrm{vol})$, centrifuged and the $\mathrm{pH}$ of the supernate adjusted to 8.2-8.4. Catecholamines were adsorbed onto alumina and eluted with $2 \mathrm{ml}$ of $0.2 \mathrm{~N}$ acetic acid. Catecholamine concentrations were determined by an automated modification of the trihydroxyindole method (19).

\section{Determination of the antagonistic potency of prazosin}

After the induction of pentobarbital anesthesia with 70 $\mathrm{mg} / \mathrm{kg}$ i.p., polyethylene catheters (o.d. $1 \mathrm{~mm}$ ) were inserted into both femoral veins and the right femoral artery. The arterial catheter was connected to a pressure transducer (P23 DB; Statham Instruments Inc., Oxnard, Calif.) and blood pressure monitored on a Grass polygraph (Grass Instrument Co., Quincy, Mass.). One venous catheter was connected to a Harvard 975 infusion pump through which norepinephrine bitartrate (Sigma Chemical Co., St. Louis, Mo.) in isotonic saline was infused at $7 \mathrm{nmol} / \mathrm{kg}$ per min. The other venous catheter was connected to a $1-\mathrm{ml}$ syringe containing prazosin in $5 \%$ dextrose $(400 \mu \mathrm{g} / \mathrm{ml})$. The response of blood pressure to norepinephrine was determined before and $15 \mathrm{~min}$ after bolus injection of prazosin.

\section{Administration of drugs}

Prazosin hydrochloride (Pfizer Inc., New York) was dissolved in $5 \%$ dextrose solution to a final concentration of $400 \mu \mathrm{g} / \mathrm{ml}$ and administered intravenously. A single $200 \mu \mathrm{g}$ dose was given immediately before the measurement of water transport.

Phentolamine mesylate (Ciba-Giegy Corp.) was dissolved in isotonic saline to a final concentration of $640 \mu \mathrm{g} / \mathrm{ml}$ and administered at a dose of $36 \mu \mathrm{g} / \mathrm{kg}$ per min i.v. simultaneously with angiotensin II or $\left(\operatorname{Sar}^{1} \mathrm{Leu}^{8}\right)$-angiotensin II during the second 15-min experimental period.

Guanethidine sulfate (Ciba-Giegy Corp.) was dissolved in isotonic saline to a final concentration of $20 \mathrm{mg} / \mathrm{ml}$. Single doses of $20 \mathrm{mg} / \mathrm{kg}$ i.p. were given 48 and $24 \mathrm{~h}$ before the measurement of water transport.

Captopril (Squibb \& Sons, Inc., Princeton, N. J.) was dissolved in isotonic saline to a final concentration of $10 \mathrm{mg} / \mathrm{ml}$. A single dose of $10 \mathrm{mg} / \mathrm{kg}$ was injected into the lumen of the duodenum $60 \mathrm{~min}$ before the measurement of water transport.

\section{Purity of analogs}

$\left(\right.$ Asp $^{1}$ Ile $\left.^{5}\right)$-angiotensin I, $\left(\right.$ Asp $^{1}$ Ile $\left.^{5}\right)$-angiotensin II (Beckman Instruments Inc., Spinco Div. Palo Alto, Calif.) and $\left(\right.$ Sar $^{1}$ Ile $^{5}$ Leu $^{8}$ )-angiotensin II (Vega-Fox Biochemicals Div., Tucson, Ariz.) were used in these experiments. The composition and purity of these peptides was verified by amino acid analysis of a $6 \mathrm{~N} \mathrm{HCl}$ hydrolysate and by silica gel thin-layer chromatography using appropriate peptide and amino acid standards. All experiments were conducted with pure peptides by these criteria. The peptides also were bioassayed with strips of rabbit thoracic aorta and on rat blood pressure. 


\section{Expression and analysis of data}

Water absorption is defined as the loss of fluid from the intestinal sac and is expressed as milliliter of water transport per gram wet weight of intestinal segment per $30 \mathrm{~min}$. There is no significant change in the water content of the jejunum after the infusion of angiotensin; the wet/dry weight ratio was $5.9 \pm 0.4$ after the infusion of saline and $6.1 \pm 0.3$ and $6.2 \pm 0.7$ after the infusion of 0.7 and $700 \mathrm{ng}$ angiotensin II $/ \mathrm{kg}$ per min, respectively. Data from similar experiments were grouped together and expressed as mean \pm 1 SE. Statistical analysis of the results was carried out using either a paried or unpaired Student's $t$ test, as appropriate. $P$ values $<0.05$ were considered statistically significant.

\section{RESULTS}

Angiotensin in sympathectomized animals (Fig. 1). Initial experiments were performed to determine the effect of angiotensin II on jejunal water transport in peripherally sympathectomized rats. Cardiac norepinephrine concentrations in sympathectomized rats were $42.4 \pm 5.0 \mathrm{ng} / \mathrm{g}$ heart $(n=6)$ compared to 189.1 $\pm 5.0 \mathrm{ng} / \mathrm{g}$ heart $(n=6)$ in normal rats. The results in Fig. 1 demonstrate that control levels of water transport in sympathectomized animals are similar to those obtained in normal animals. Infusion of angiotensin II into normal animals at a subpressor dose of $0.7 \mathrm{ng} / \mathrm{kg}$ per min significantly stimulated the rate of net absorption from the sac, but at a pressor dose of $700 \mathrm{ng} / \mathrm{kg}$ per min angiotensin II inhibited water transport significantly. In contrast, the stimulation of water transport in response to low dose infusion of angiotensin II was abolished in sympathectomized rats, whereas at 700 $\mathrm{ng} / \mathrm{kg}$ per min the hormone significantly inhibited transfer. When the results are expressed as transport in the second experimental period as a percentage of transport in the first (control) period, the inhibitory response to $700 \mathrm{ng} / \mathrm{kg}$ per min angiotensin was potentiated in sympathectomized animals $(73.1 \pm 6.5 \%$ in normal and $21.7 \pm 17.6 \%$ in sympathectomized animals, $P<0.05$ ).

Angiotensin in guanethidine-treated animals (Fig. 2). The dose-dependent responses of jejunal water absorption induced by angiotensin II in adult animals pretreated acutely with guanethidine $(20 \mathrm{mg} / \mathrm{kg}$ for $2 \mathrm{~d}$ ) are shown in Fig. 2. This dose of guanethidine was twice that required to reduce cardiac norepinephrine content by over $90 \%$ (20). In the absence of guanethidine treatment, angiotensin II exhibited a dose-dependent dual action on jejunal absorption. The peptide significantly stimulated water transfer when infused at doses less than $70 \mathrm{ng} / \mathrm{kg}$ per min. After pretreatment of the animals with guanethidine, angiotensin II failed to stimulate water transfer above control levels. However, infusion of angiotensin II at $70 \mathrm{ng} / \mathrm{kg}$ per min resulted in a significant inhibition of water transport below control levels $(108.1 \pm 10.2 \%$ to 38.5 $\pm 17.3 \%, P<0.05)$. When infused at $700 \mathrm{ng} / \mathrm{kg}$ per $\mathrm{min}$

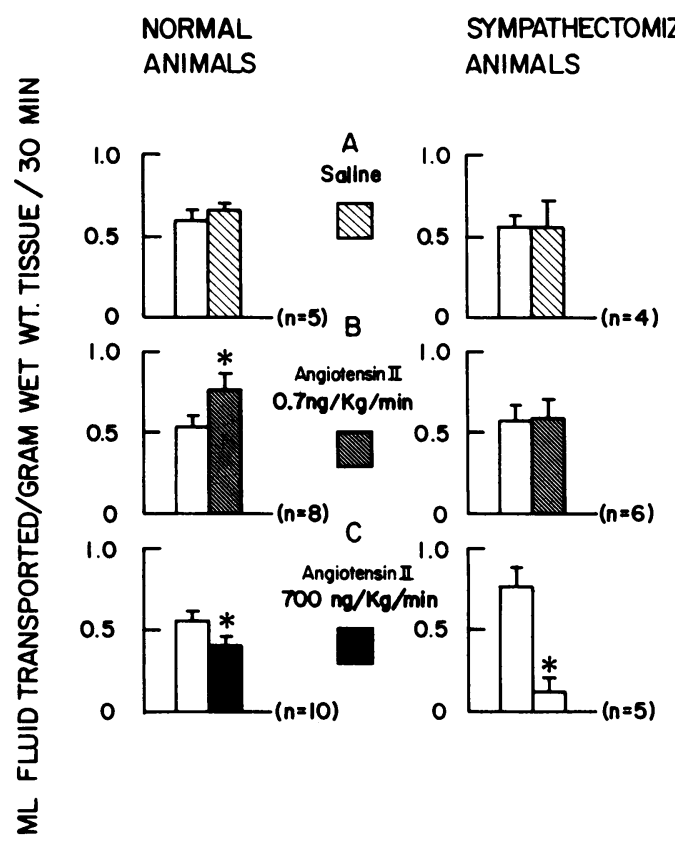

Figure 1 Effect of angiotensin II on jejunal water transport in normal and sympathectomized animals. Histograms represent the mean $\pm 1 \mathrm{SE}$ of jejunal water transport measured over two consecutive 15 min periods in separate animals: (A) isotonic saline was infused during both periods; (B) isotonic saline was infused during first period and angiotensin II $(0.7 \mathrm{ng} / \mathrm{kg}$ per min) was infused during second period; and (C) isotonic saline was infused during first period and angiotensin II (700 $\mathrm{ng} / \mathrm{kg}$ per min) during second period. Statistics compare changes in the second (experimental) period with the first (control) period. ${ }^{*} P<0.05,{ }^{* *} P<0.01$. Peripheral sympathectomy was induced in newborn rats after subcutaneous injection of guanethidine $(50 \mathrm{mg} / \mathrm{kg}) 5 \mathrm{~d} / \mathrm{wk}$ for $3 \mathrm{wk}$

angiotensin II induced an almost identical inhibition of transport in both normal and guanethidine treated animals.

Angiotensin in adrenalectomized animals (Fig. 3). The results in Fig. 3 demonstrate that control levels of water absorption in rats $24 \mathrm{~h}$ after adrenalectomy were similar to those obtained in normal animals. Infusion of low dose angiotensin II ( $7 \mathrm{ng} / \mathrm{kg}$ per min) significantly stimulated jejunal water transport to an extent comparable in both normal and adrenalectomized rats. Angiotensin II at $700 \mathrm{ng} / \mathrm{kg}$ per min significantly inhibited water transport in both intact and adrenalectomized rats. As with sympathectomized animals, when the results are expressed as transport in the second (experimental) period as a percentage of transport in the first (control) period, it is evident that the inhibitory response to high dose angiotensin II was significantly potentiated in adrenalectomized rats $(73.1 \pm 6.5 \%$ in control and $21.7 \pm 17.6 \%$ in adrenalectomized rats, $P<0.05$ ).

Effect of angiotensin analog on plasma renin activity 


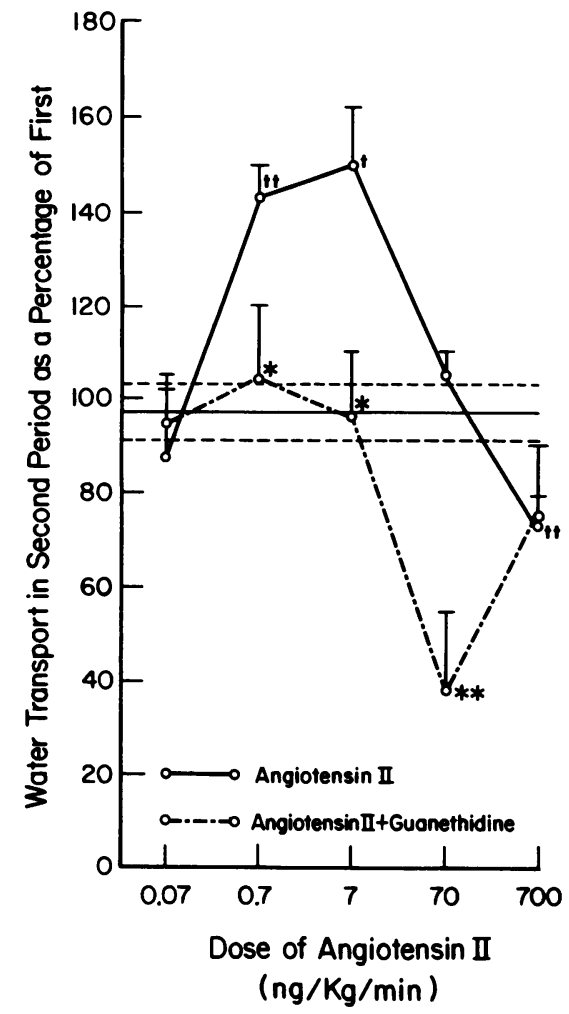

FIGURE 2 Effect of angiotensin II on jejunal water transport in the presence and absence of guanethidine. Results are expressed as percent change of water transport in the experimental animals in the second period when angiotensin was infused above that in the first period when saline was infused. Horizontal line and accompanying broken lines represent the mean $\pm \mathrm{SE}$ of the change occuring when saline was infused over both periods in the absence of guanethidine (control animals). Guanethidine did not affect the percent change in water transfer occuring in control animals, 96.8 $\pm 5.6(n=5)$ in the absence of guanethidine and $108.1 \pm 10.2$ $(n=5)$ in the presence of guanethidine. Each point represents the mean $\pm 1 \mathrm{SE}$ from 4 to 17 observations. ${ }^{*}, \uparrow P<0.05$, $* *, \uparrow \uparrow P<0.01$. Statistics are relative to the percent change in water transport induced by angiotensin in the presence and absence of guanethidine $\left({ }^{*}\right)$ or are relative to the changes in water absorption produced by angiotensin II above control animals $(\uparrow)$. Guanethidine $(20 \mathrm{mg} / \mathrm{kg})$ was injected 48 and $24 \mathrm{~h}$ before the measurement of water transport.

(Fig. 4). Infusion of $\left(\mathrm{Sar}^{1} \mathrm{Leu}^{8}\right)$-angiotensin II at doses that stimulated jejunal water transport $(0.7-70 \mathrm{ng} / \mathrm{kg}$ per min) failed to change plasma renin activity significantly.

Angiotensin analog after nephrectomy (Fig. 5). Prior bilateral nephrectomy had no significant effect upon control levels of water absorption measured over two consecutive 15-min periods. Nephrectomy also had no significant effect upon the stimulation of water transport induced by $\left(\operatorname{Sar}^{1} \mathrm{Leu}^{8}\right)$-angiotensin II $(7 \mathrm{ng} / \mathrm{kg}$ per min).

Angiotensin analog in captopril-treated animals

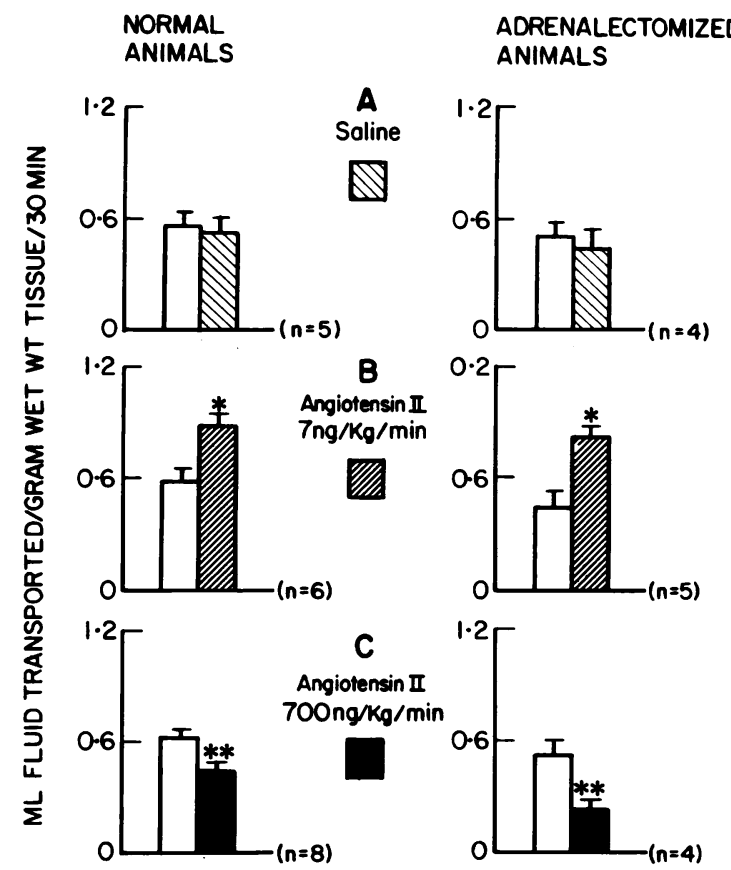

Figure 3 Effect of angiotensin II on jejunal water transport after adrenalectomy. Histograms represent the mean \pm 1 $\mathrm{SE}$ of jejunal water transport measured over two consecutive 15 min periods in separate animals: (A) isotonic saline was infused during both periods; (B) isotonic saline was infused in the first period and angiotensin II ( $7 \mathrm{ng} / \mathrm{kg}$ per min) was infused during the second period; and $(C)$ isotonic saline was infused in the first period and angiotensin II $(700 \mathrm{ng} / \mathrm{kg}$ per min) during the second period. ${ }^{*} P<0.05,{ }^{* *} P<0.01$. Statistics compare changes in second (experimental) period with the first (control) period. Adrenalectomy was performed $24 \mathrm{~h}$ before the measurement of water transport.

(Table I; Fig. 6). Plasma converting enzyme activity was inhibited totally 60 and $90 \mathrm{~min}$ after administration of $10 \mathrm{mg} / \mathrm{kg}$ captopril (Table I). Captopril pretreatment (Fig. 6) had no significant effect upon control levels of water absorption or the stimulation of transport induced by low dose infusion of angiotensin II or $\left(\mathrm{Sar}^{1} \mathrm{Leu}^{8}\right)$ angiotensin II ( $7 \mathrm{ng} / \mathrm{kg}$ per $\mathrm{min})$. Angiotensin I signficantly stimulated jejunal water transport at a dose of $7 \mathrm{ng} / \mathrm{kg}$ per min, and this response was abolished after captopril pretreatment.

Effect of angiotensin in phentolamine- and prazosintreated animals (Fig. 7). Phentolamine (36 $\mu \mathrm{g} / \mathrm{kg}$ per min) abolishes the stimulation of jejunal water absorption and the associated increase in systemic blood pressure produced by infusion of $7 \mathrm{nmol} /$ $\mathrm{kg}$ per min norepinephrine (9). Similarly, in the present study, pretreatment of the animals with prazosin (200 $\mu \mathrm{g})$ attenuated the increase in blood pressure in response to $7 \mathrm{nmol} / \mathrm{kg}$ per min norepinephrine $(88 \pm 9.0$ $-151 \pm 4.0$ to $71 \pm 4.9-91 \pm 4.0 \mathrm{~mm} \mathrm{Hg}$ ). The dosedependent responses of jejunal water absorption in- 

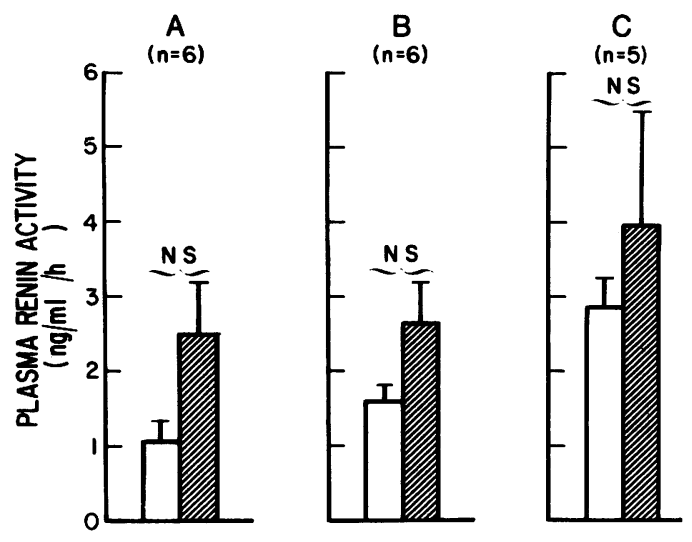

FIGURE 4 Effect of $\left(\mathrm{Sar}^{1} \mathrm{Leu}^{8}\right)$-angiotensin II on plasma renin activity. Histograms represent the mean $\pm 1 \mathrm{SE}$ of plasma renin activity measured immediately before and immediately after a $15 \mathrm{~min}$ intravenous infusion of $\left(\mathrm{Sar}^{1} \mathrm{Leu}^{8}\right)$-angiotensin II in separate animals: (A) $\left(\mathrm{Sar}^{1} \mathrm{Leu}^{8}\right)$-angiotensin II was infused at $0.7 \mathrm{ng} / \mathrm{kg}$ per $\mathrm{min}$; (B) $\left(\mathrm{Sar}^{1} \mathrm{Leu}^{8}\right)$-angiotensin II was infused at $7.0 \mathrm{ng} / \mathrm{kg}$ per $\mathrm{min}$; and (C) $\left(\mathrm{Sar}^{1} \mathrm{Leu}^{8}\right)$-angiotensin II infused at $70 \mathrm{ng} / \mathrm{kg}$ per min. Statistics compare changes in plasma renin activity before and after $\left(\mathrm{Sar}^{1} \mathrm{Leu}^{8}\right)$-angiotensin infusion.

duced by angiotensin II in the presence and absence of phentolamine or prazosin are shown in Fig. 7. In the presence of either $\alpha$-adrenergic antagonist, angiotensin II failed to stimulate jejunal water transport.

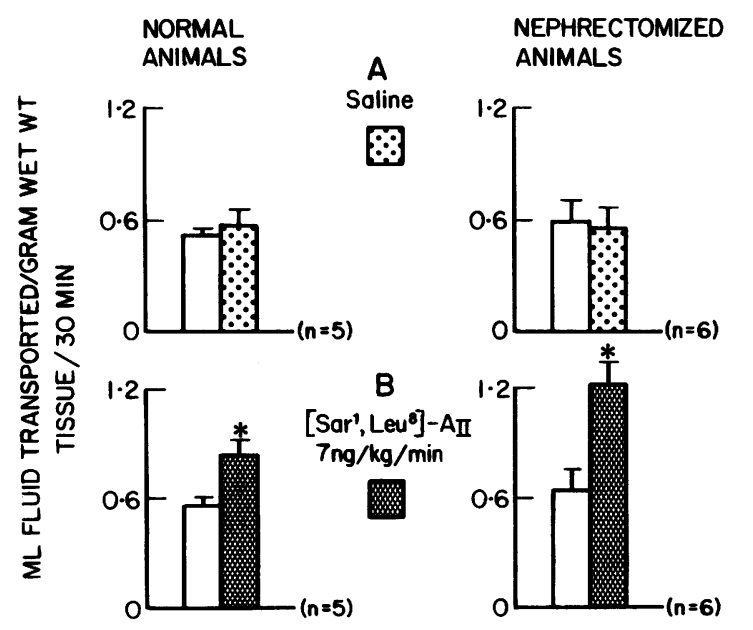

Figure 5 Effect of $\left(\operatorname{Sar}^{1} \mathrm{Leu}^{8}\right)$-angiotensin II on jejunal water transport following bilateral nephrectomy. Histograms represent the mean $\pm 1 \mathrm{SE}$ of jejunal water transport measured over two consecutive 15-min periods in separate animals: (A) isotonic saline was infused during both periods and (B) isotonic saline was infused during the first period and (Sar ${ }^{1}$ $\mathrm{Leu}^{8}$ )-angiotensin II (7 $\mathrm{ng} / \mathrm{kg}$ per min) was infused during the second period. ${ }^{*} P<0.05,{ }^{*} P<0.01$. Statistics compare changes in the second (experimental) period with first (control) period. Bilateral nephrectomy was performed $3 \mathrm{~h}$ before the measurement of jejunal water transport.
TABLE I

Effect of Captopril on Plasma Converting Enzyme Activity

\begin{tabular}{rccc}
\hline \multicolumn{4}{c}{ Plasma converting enzyme activity } \\
\cline { 2 - 4 } Time & $\begin{array}{c}\text { Untreated } \\
\text { animals }\end{array}$ & $\begin{array}{c}\text { Captopril-treated } \\
\text { animals }\end{array}$ & $P$ \\
\hline $\min$ & \multicolumn{3}{c}{ nmol hippuric acid/min/ml plasma } \\
0 & $205.9 \pm 20.1$ & $206.9 \pm 18.6$ & NS \\
60 & $216.3 \pm 28.3$ & $-3.46 \pm 1.25$ & $<0.001$ \\
90 & $228.1 \pm 31.1$ & $-2.7 \pm 1.27$ & $<0.001$
\end{tabular}

Captopril $(10 \mathrm{mg} / \mathrm{kg})$ was injected into the lumen of the duodenum at time 0 . Numbers represent mean $\pm S E$ of six experimental observations. Statistics refer to the values obtained in captopril-treated animals compared to untreated (control) animals. Half-milliliter samples of blood were drawn from a catheter implanted into the femoral vein in anesthetized rats at 0,60 , and $90 \mathrm{~min}$ after administration of captopril. In some experiments, the quantity of $\left[{ }^{3} \mathrm{H}\right]$ hippuric acid entering the ethyl acetate phase during extraction was less than the blank, thus accounting for the small negative values.

However, in the presence of phentolamine and prazosin high doses of peptide significantly inhibited water transport below the corresponding levels of absorption in untreated animals. Neither inhibitor altered basal levels of water absorption.

Effect of angiotensin analog in phentolamine-treated animals (Fig. 8). Further experiments were performed to compare the fluid transport responses elicited by $\left(\mathrm{Sar}^{1} \mathrm{Leu}^{8}\right)$-angiotensin II and those of angiotensin II. Infusion of $\left(\mathrm{Sar}^{1} \mathrm{Leu}^{8}\right)$-angiotensin II at $700 \mathrm{ng} / \mathrm{kg}$ per min significantly stimulated jejunal water transport, while infusion of angiotensin II at the same dose significantly inhibited transport. Simultaneous infusion of both peptides at $700 \mathrm{ng} / \mathrm{kg}$ per min resulted in a significant stimulation of transport above control levels. In the presence of phentolamine (36 $\mu \mathrm{g} / \mathrm{kg}$ per min) the stimulation of transport induced by $\left(\mathrm{Sar}^{1} \mathrm{Leu}^{8}\right)$-angiotensin II and the combination of the two peptides was reduced to control levels. Furthermore, the inhibition of water transport in response to angiotensin II was enhanced in the presence of phentolamine.

\section{DISCUSSION}

Angiotensin II interacts with the sympathetic nervous system at multiple sites. The hormone facilitates adrenergic neurotransmission and stimulates autonomic ganglia and adrenal catecholamine release (10, 21). Thus, previous studies using the $\alpha$-adrenergic antagonists, phentolamine, and dihydroergotamine, or reserpine, which depletes central and peripheral nerves and the adrenal medulla of catecholamines, have not established the site of interaction of angiotensin II with the sympathetic nervous system in the 
EFFECT OF CAPTOPRIL ON RESPONSE OF JEJUNUM

TO ANGIOTENSINS
NORMAL ANIMALS

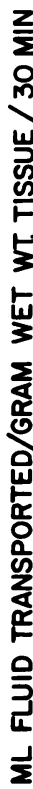

CAPTOPRIL TREATED ANIMALS
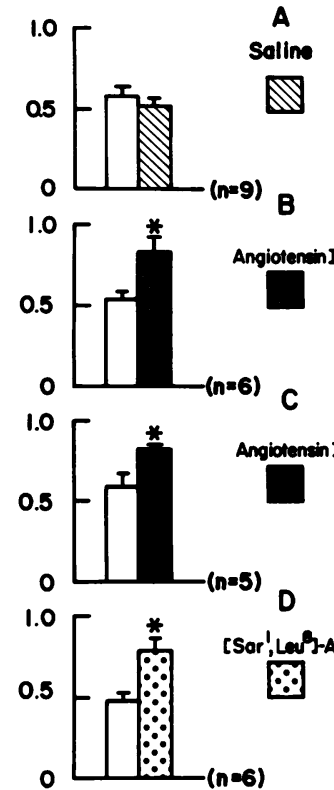

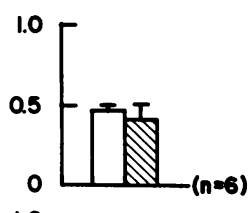

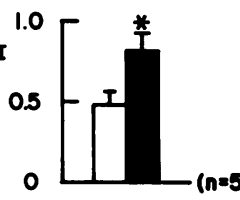

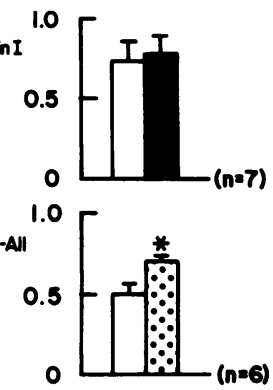

Figure 6 Effect of angiotensin II, angiotensin I and (Sar1$\mathrm{Leu}^{8}$ )-angiotensin II on jejunal water transport in the presence and absence of captopril. Histograms represent the mean $\pm S E$ of jejunal water transport measured over two consecutive 15 min periods in separate animals; (A) isotonic saline was infused during both periods; (B) isotonic saline was infused during the first period and angiotensin II ( $7 \mathrm{ng} / \mathrm{kg}$ per min) during the second period; (C) isotonic saline was infused during the first period and angiotensin I ( $7 \mathrm{ng} / \mathrm{kg}$ per min) infused during the second period; and (D) isotonic saline was infused during the first period and $\left(\mathrm{Sar}^{1} \mathrm{Leu}^{8}\right)$-angiotensin II infused during the second period. ${ }^{*} P<0.05$. Statistics compare changes in the second (experimental) period with the initial (control) period. In these experiments captopril (10 $\mathrm{mg} / \mathrm{kg}$ ) was injected into the lumen of the duodunum $60 \mathrm{~min}$ before the experiments for the measurement of water transport.

control of intestinal sodium and water absorption. In the present study, we sought to characterize this locus of hormone interaction.

Chronic administration of guanethedine to newborn animals leads to permanent destruction of peripheral sympathetic nerve fibers, but leaves central adrenergic fibers and the adrenal medulla intact (16). Guanethidine is taken up selectively into peripheral sympathetic nerve endings and slowly releases catecholamines from storage granules, ultimately depleting autonomic nerve fibers of neurotransmitter (22). In newborn animals, guanethidine also inhibits the action of nerve growth factors (23). These actions of guanethidine

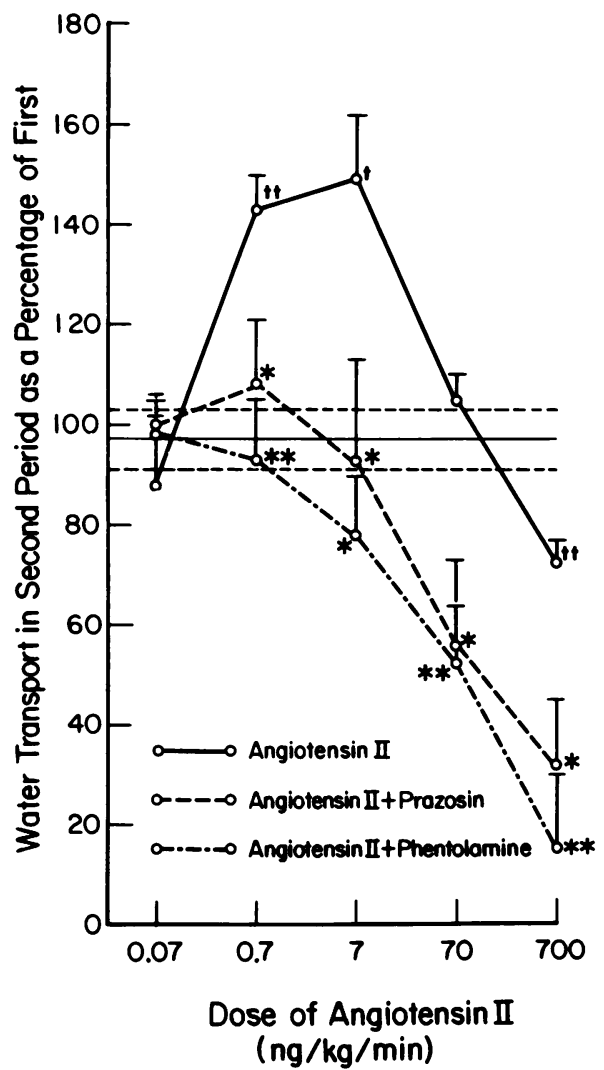

FIGURE 7 Effect of angiotensin II on jejunal water transport in the presence of phentolamine and prazosin. Results are expressed as percent change of water transport in the experimental animals in the second period when angiotensin was infused above that in the first period when saline was infused. Horizontal and accompanying broken lines represent the mean $\pm 1 \mathrm{SE}$ of the change that occurred when saline was infused over both periods in the absence of phentolamine and prazosin (control animals). Neither alpha blocker affected the percent change in transfer which occurred in control animals, 96.8 $\pm 5.6(n=5)$ in the absence and 95.0 \pm 23.7 $(n=6)$ and $106.3 \pm 13.6(n=5)$ in the presence of phentolamine and prazosin, respectively. Each point represents the mean $\pm 1 \mathrm{SE}$ from 4 to 17 observations. ${ }^{*} \uparrow P<0.05$, $* * \uparrow \uparrow P<0.01$. Statistics are relative to the percent change in water transport produced by angiotensin in the presence or absence of phentolamine or prazosin $\left({ }^{*}\right)$ or are relative to the changes in water absorption produced by angiotensin II above control animals $(\uparrow)$. Phentolamine was infused simultaneously with angiotensin II at a rate of $36 \mu \mathrm{g} / \mathrm{kg}$ per min during the second experimental period. Prazosin $(200 \mu \mathrm{g})$ was injected intravenously immediately before the measurement of water transport over two consecutive 15 min periods.

lead to loss of catecholamines and destruction of peripheral sympathetic nerves.

In the present study, angiotensin II failed to produce the characteristic stimulation of jejunal water transport in sympathectomized animals. This observation suggests that angiotensin II-stimulated water transport is not mediated by adrenal catecholamine release. The 
NORMAL

ANIMALS

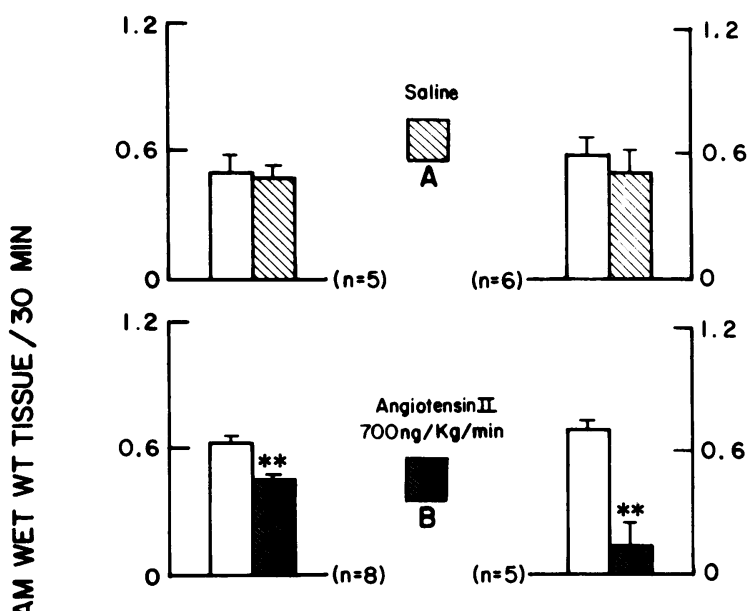

PHENTOLAMINE TREATED ANIMALS
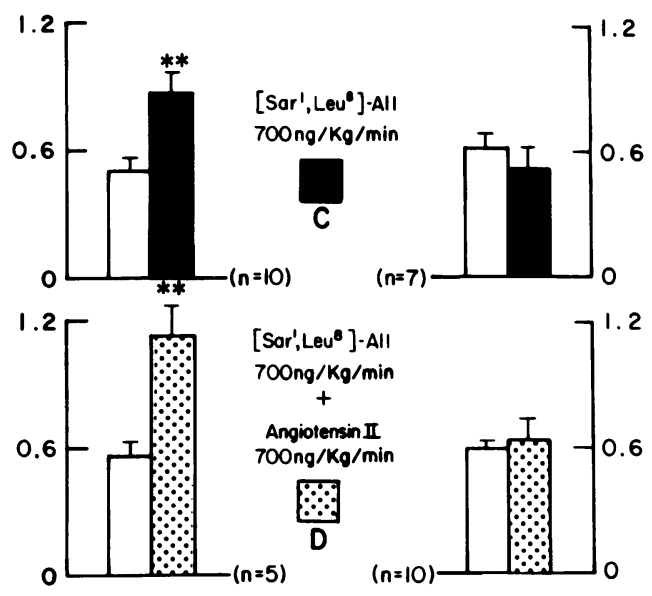

FIGURE 8 Effect of angiotensin II and $\left(\operatorname{Sar}^{1} \mathrm{Leu}^{8}\right)$-angiotensin on jejunal water transport in the presence and absence of phentolamine. Histograms represent the mean $\pm 1 \mathrm{SE}$ of jejunal water transport measured over two consecutive $15 \mathrm{~min}$ periods in separate animals: (A) isotonic saline was infused during both periods; (B) isotonic saline was infused during the first period and angiotensin II (700 $\mathrm{ng} / \mathrm{kg}$ per $\mathrm{min}$ ) infused during the second period; $(\mathrm{C})$ isotonic saline was infused during the first period and $\left(\operatorname{Sar}^{1} \mathrm{Leu}^{8}\right)$-angiotensin II (700 $\mathrm{ng} / \mathrm{kg}$ per $\mathrm{min}$ ) infused during the second period; and (D) isotonic saline was infused during the first period and angiotensin II and $\left(\mathrm{Sar}^{1} \mathrm{Leu}^{8}\right)$-angiotensin II were infused simultaneously at $700 \mathrm{ng} / \mathrm{kg}$ per min during the second period. * $P<0.05$, ** $P<0.01$. Statistics compare changes in the second (experimental) period with the first (control) period. Phentolamine was infused simultaneously with angiotensin II at a rate of $36 \mu \mathrm{g} / \mathrm{kg}$ per min during the second (experimental) period.

demonstrated failure of bilateral adrenalectomy to block the stimulatory response also supports this concept. It is well-known that after denervation effector organs become supersensitive to the effects of endog- enous neurotransmitter (24). Because exogenous norepinephrine exhibits a dose-dependent dual action on jejunal water transport (9), it is possible in our sympathectomy experiments that denervation supersensitivity could have altered responses of the jejunum to endogenously released norepinephrine. However, angiotensin II failed to stimulate jejunal transport at any dose in sympathectomized rats or animals acutely treated with guanethidine. Therefore, increased peripheral sympathetic neuronal activity must be responsible for the stimulation of jejunal water transport after administration of low doses of angiotensin II. Further, catecholamines are not mediators of the inhibitory response to high doses of peptide.

Physiological concentrations of angiotensin II act in the central nervous system to produce thirst (1), salt appetite (25), and increased sympathetic outflow, resulting in elevation of systemic arterial pressure (26). Therefore, it is possible that angiotensin II may act in the central nervous system to increase sympathetic outflow and, hence, jejunal water transport. Angiotensin II has been shown repeatedly to stimulate intestinal sodium and water transport in vitro $(6,27)$. The hormone also stimulates sodium and water transport in intestinal preparations stripped of neural plexi (6). Therefore, it is most unlikely that angiotensin II stimulates jejunal absorption either by an action on the central nervous system or autonomic ganglia.

In addition to combining with $\alpha_{1}$-adrenergic receptors at postsynaptic membranes, norepinephrine exerts negative feedback on catecholamine release from adrenergic nerve endings by combining with $\alpha_{2}$ receptors on the presynaptic neural membrane (10). The $\alpha$-adrenergic antagonists, phentolamine and dihydroergotamine, alter sympathetic function by combining with both $\alpha_{1}$ - and $\alpha_{2}$-receptors (10). Therefore, with these pharmacological agents, it is not possible to determine on which side of the synapse released norepinephrine affects intestinal sodium and water transport. The $\alpha$-adrenergic antagonist, prazosin, has high affinity and specificity for postsynaptic $\alpha_{1}$-receptors (28). In the present study, both prazosin and phentolamine inhibited angiotensin II-stimulated water transport. Therefore, angiotensin II must bind to receptors located on postganglionic sympathetic nerve terminals in close proximity to the transporting epithelial cells of the intestine, resulting in facilitation of norepinephrine release. The liberated norepinephrine subsequently must bind to $\alpha_{1}$-receptors leading to increase sodium and water transport. The location of the postsynaptic $\alpha$ receptors is unknown at the present time. They may be located on the basalateral membranes of the enterocyte and intimately linked to transepithelial transport processes. However, it is also possible that the $\alpha_{1}$-receptor is located on paracrine 
cells or peptidergic nerve terminals that release absorptive stimulating hormones onto the enterocyte in response to stimulation by norepinephrine (29).

It is becoming increasingly clear that both absorptive and secretory processes occur simultaneously within the intestine. Under normal physiological conditions, absorption usually is greater than secretion, leading to a net uptake of ions and water from the intestinal lumen. Stimulation of intestinal $\alpha$-adrenergic receptors increases sodium absorption and inhibits opposing secretion (30). In contrast, hormones such as vasoactive intestinal peptide and prostaglandins of the $\mathrm{E}$ and $\mathrm{F}$ series inhibit the coupled absorption of sodium and chloride and stimulate ion secretion (30). Angiotensin II also appears to stimulate absorptive and secretory processes simultaneously within the intestine (8). At low doses the stimulatory (sympathetic) response predominates, whereas at progressively higher doses the peptide induces dose-dependent prostaglandin production which leads to increased secretion.

In the present study, the inhibition of transport induced by high doses of angiotensin II was significantly potentiated in sympathectomized animals. As angiotensin II simultaneously stimulates both absorptive and secretory processes in the intestine, it is possible after sympathectomy that only the secretory response to the hormone is elicited after administration of high doses of angiotensin leading to an apparently greater inhibition of absorption. This hypothesis is supported by the finding that angiotensin IIinhibited water transport also was potentiated in the presence of phentolamine and prazosin. The stimulation of absorption in response to angiotensin II was abolished and a potentiated inhibition of transport was expressed in rats treated acutely with guanethidine. However, at the highest dose of angiotensin II infused, transport returned towards control levels. The lack of a potentiated inhibition of absorption at high doses of angiotensin II may be due to adrenal catecholamine release leading to increased absorption, since angiotensin II-inhibited water transport was significantly potentiated in adrenalectomized rats. Furthermore, a greater percentage of the adrenal medulla may have been destroyed in sympathectomized animals than in those animals acutely treated with guanethidine. Thus, the lack of a potentiated inhibition of absorption at high doses of angiotensin II in rats acutely treated with guanethidine may also be due to a relatively greater quantity of medullary norepinephrine release than in sympathectomized animals.

Analogs of angiotensin II substituted with aliphatic amino acids for the COOH-terminal phenylalanine possess low intrinsic activity and are potent competitive inhibitors of the parent peptide in both pressor and myotropic systems (11). However, the substituted analog $\left(\mathrm{Sar}^{1} \mathrm{Leu}^{8}\right)$-angiotensin II has even greater potency than the parent peptide in stimulating jejunal water absorption. Infusion of peptide inhibitors of angiotensin II in-vivo consistently elevates plasma renin activity $(31,32)$. Furthermore, increased renal sympathetic neuronal activity is a potent stimulus for renin release from the kidney (33). Angiotensin II antagonists possess significant agonist activity in facilitating sympathetic neurotransmission and stimulating the release of adrenal catecholamines (34, $35)$. In the present study, infusion of $\left(\mathrm{Sar}^{1} \mathrm{Leu}^{8}\right)$ angiotensin II at doses which significantly stimulated jejunal water absorption increased plasma renin activity, although not significantly. It is still possible that the stimulation of jejunal transport in response to $\left(\mathrm{Sar}^{1} \mathrm{Leu}^{8}\right)$-angiotensin II may have been at least in part due to increased endogenous angiotensin II production mediated by a small enhancement of renin release. However, $\left(\operatorname{Sar}^{1} \mathrm{Leu}^{8}\right)$-angiotensin II produced identical stimulation of jejunal water transport before and after disruption of the renin-angiotensin system with captopril. In the presence of captopril, increased plasma renin activity produces elevated endogenous plasma angiotensin I concentrations (36). In the present study, exogenous angiotensin I had no significant direct effect upon jejunal water transport. Also, acute nephrectomy did not alter the ability of $\left(\mathrm{Sar}^{1} \mathrm{Leu}^{8}\right)$-angiotensin II to stimulate jejunal water absorption. Therefore, the stimulation of jejunal transport during administration of $\left(\mathrm{Sar}^{1} \mathrm{Leu}^{8}\right)$-angiotensin II could not have been related to enhanced endogenous angiotensin II production as a result of renal renin release.

The stimulation of jejunal sodium and water absorption after administration of $\left(\mathrm{Sar}^{1} \mathrm{Leu}^{8}\right)$-angiotensin II was abolished by phentolamine. This suggests that the analog stimulates jejunal water transport by facilitating norepinephrine release from sympathetic nerve endings. In previous studies, simultaneous infusion of high doses of angiotensin II and $\left(\operatorname{Sar}^{1} \mathrm{Leu}^{8}\right)$-angiotensin II resulted in stimulation of jejunal water transport $115 \%$ above basal levels, suggesting that the analog may block the inhibition of water transport or stimulation of secretion in response to high doses of angiotensin II (8). In the present study, simultaneous infusion of phentolamine blocked the enhanced stimulation of absorption in response to both compounds. However, no inhibitory response was expressed. Therefore, $\left(\mathrm{Sar}^{1} \mathrm{Leu}^{8}\right)$-angiotensin II is devoid of agonist activity in stimulating endogenous intestinal prostaglandin production, and the analog may be an antagonist of the secretory response or inhibition of transport induced by angiotensin II.

On the basis of the observations reported here, 
we have developed a model to explain the effects of angiotensin II on jejunal water transport. The model predicts that at low doses angiotensin II interacts with a high affinity receptor on postganglionic sympathetic nerve endings in close proximity to the transporting epithelial cells. The released norepinephrine subsequently binds to postsynaptic $\alpha_{1}$-receptors on the basolateral membrane of the epithelial cells, leading to increased sodium and water absorption. At higher doses, angiotensin II interacts with a lower affinity receptor on epithelial cells to stimulate the production of endogenous prostaglandins, resulting in decreased absorption and/or increased secretion. The analog $\left(\right.$ Sar $_{1}{ }^{-}$ $\mathrm{Leu}^{8}$ )-angiotensin II is a full agonist at stimulating norepinephrine release from sympathetic nerve endings (i.e., increased transport) but is an antagonist of angiotensin II-induced intestinal prostaglandin production.

Diarrhea is a major public health problem particularly in developing countries. Recently, it has been demonstrated that diarrhea can occur either by inhibition of absorptive processes or by stimulation of secretory process. Diarrhea can lead to massive water and electrolyte loss, contraction of extracellular fluid volume, circulatory collapse, and death. Therefore, extensive research has been directed to develop drugs capable of countering diarrhea either by stimulating absorption or inhibiting secretion (37). After a small reduction of the extracellular fluid volume, renin is released and angiotensin II generated. According to our model, angiotensin II should act upon all areas of the intestine to increase sodium chloride and water absorption. However, after severe contraction of the extracellular fluid volume plasma angiotensin II concentrations increase above the physiological range and cardiovascular integrity is maintained by angiotensin II-mediated vasoconstriction. For example, plasma angiotensin II concentrations of $1,300 \mathrm{pg} / \mathrm{ml}$ have been recorded after severe hemorrhage (38). After elevation of plasma angiotensin II concentrations to $400 \mathrm{pg} / \mathrm{ml}$, the hormone inhibits intestinal absorption or stimulates secretion (39), compounding the consequences of electrolyte and water loss accompaning severe diarrhea. We have shown that a COOH-terminally substituted analog of angiotensin II approximately doubles basal intestinal sodium and water transport and abolishes the inhibition of absorption or stimulation of secretion produced by elevated levels of angiotensin II. Such an angiotensin II antagonist also is a full agonist in stimulating renal sodium and water absorption (40). Therefore, we speculate that analogs of angiotensin II may be of value as an adjunct to the therapy of diseases characterized by contraction of the extracellular fluid volume, such as chronic diarrhea.

\section{ACKNOWLEDGMENTS}

The authors are pleased to acknowledge the assistance of Ms. Ceridwen Daniel to these studies and Ms. Judy Woodson for typing the manuscript. Thanks are extended to Mr. M. C. Brownley of Ciba Pharmaceuticals and Dr. E. M. Weiss of Pfixer Laboratories for supplying guanethadine sulfate and prazosin hydrochloride, respectively.

\section{REFERENCES}

1. Fitzsimons, J. T. 1972. Thirst. Physiol. Rev. 52: 1157-1175.

2. Davis, J. O. 1974. The renin-angiotensin system in the control of aldosterone secretion. In Handbook of Experimental Pharmacology. I. H. Page and F. M. Bumpus, editors. Springer-Verlag, New York. 37: 289-331.

3. Malvin, R. L. 1971. Possible role of the renin-angiotensin system in the regulation of antidiuretic hormone secretion. Fed. Proc. 30: 1383-1386.

4. Harris, P. J., and J. A. Young. 1977. Dose dependent stimulation and inhibition of proximal tubular sodium reabsorption by angiotensin II in the rat kidney. Pfluegers Arch. 367: 295-297.

5. Munday, K. A., B. J. Parsons, and J. A. Poat. 1971. The effect of angiotensin on cation transport by rat kidney cortex slices. J. Physiol. (Lond.). 215: 269-282.

6. Davies, N. T., K. A. Munday, and B. J. Parsons. 1970. The effect of angiotensin on rat intestinal fluid transfer. J. Endocrinol. 48: 39-46.

7. Bolton, J. E., K. A. Munday, B. J. Parsons, and B. G. York. 1975. Effects of angiotensin II on fluid transport, transmural potential difference and blood flow by rat jejunum in-vivo. J. Physiol. 253: 411-428.

8. Levens, N. R., M. J. Peach, R. M. Carey, J. A. Poat, and K. A. Munday. 1981. Response of rat jejunum to angiotensin II: role of norepinephrine and prostaglandins. Am. J. Physiol. 240: G17-G24.

9. Levens, N. R., K. A. Munday, B. J. Parsons, J. A. Poat, and C. P. Stewart. 1979. Noradrenaline as a possible mediator of the actions of angiotensin on fluid transport by rat jejunum in-vivo. J. Physiol. 286: 351-360.

10. Starke, K. 1977. Regulation of noradrenaline release by presynaptic receptor systems. Rev. Physiol. Biochem. Exp. Pharmacol. 77: 1-124.

11. Khosla, M. C., R. R. Smeby, and F. M. Bumpus. 1974. Structure-activity relationship in angiotensin II analogs. In Handbook of Experimental Pharmacology. I. H. Page and F. M. Bumpus, editors. Springer-Verlag Inc., New York. 37: 126-161.

12. Levens, N. R., M. J. Peach, R. M. Carey, J. A. Poat, and K. A. Munday. 1980. Stimulation of intestinal sodium and water transport in vivo by angiotensin II and analogs. Endocrinology. 107: 1946-1953.

13. Blair-West, J. R., R. P. Coghlan, D. A. Denton, J. W. Funder, B. A. Scoggins, and R. D. Wright. 1971. Inhibition of renin secretion by systemic and intrarenal angiotensin infusion. Am. J. Physiol. 220: 1309-1315.

14. Krebs, H. A., and K. Henseleit. 1932. Untersuchunger uber die Hornstoffbildung in Tiefkiper. Hoppe-Seyler's Z. Physiol. Chem. 210: 33-66.

15. Levens, N. R. 1977. Studies on the mechanism of action of angiotensin II. Ph.D. Thesis, University of Southampton.

16. Johnson, E. M., F. O. Brien, and R. Werbitt. 1976 Modification and characterization of the permanent sympathectomy produced by the administration of 
guanethidine to newborn rats. Eur. J. Pharmacol. 37: 45-54.

17. Cushman, D. W., and H. S. Cheung. 1971. Spectrophotometric assay and properties of the angiotensinconverting enzyme of rabbit lung. Biochem. Pharmacol. 20: $1637-1648$.

18. Haber, E., T. Koerner, L. B. Page, B. Kiliman, and A Purnodo. 1969. Application of radioimmunoassay for angiotensin I to the physiologic measurements of plasma renin activity in normal human subjects. J. Clin. Endocrinol. Metab. 29: 1349-1355.

19. Chang, C. C. 1964. A sensitive method for spectrophotofluoremetric assay of catecholamines. Int. J. Neuropharmacol. 3: 643-651.

20. Westfall, T. C., and H. Osada. 1968. Influence of adrenalectomy on the repletion of norepinephrine following treatment with metaraminol or guanethidine. Fed. Proc. 27: 601. (Abstr.)

21. Turker, R. K., and S. O. Kayaalp. 1967. Inhibitory effect of angiotensin on intestinal motility of the cat and its relation to sympathetic nervous system. Arch. Int. Physiol. Biochim. 75: 735-744.

22. Nickerson, M., and B. Collier. 1975. Drugs inhibiting adrenergic nerves and structures innervated by them. In The Pharmacological Basis of Therapeutics. L. S. Goodman and A. Gilman, editors. Macmillan, Inc., New York. 533-564.

23. Johnson, E. M., and L. Alee. 1974. Suppression of the invitro and in-vivo cytotoxic effects of guanethidine in sympathetic neurons by nerve growth factor. Brain Res. 81: 519-532.

24. Tredelenburg, U. 1972. Factors influencing the concentration of catecholamines at the receptors. In Handbook of Experimental Pharmacology. H. Biaschko and E. Muschall, editors. Springer Verlag Inc., New York. 33: 726-761.

25. Chiaraviglio, E. 1976. Effect of renin-angiotensin system on sodium intake. J. Physiol. 255: 57-66.

26. Buckley, J. P. 1972. Actions of angiotensin on the central nervous system. Fed. Proc. 31: 1332-1337.

27. Crocker, A., and K. A. Munday. 1967. Aldosterone and angiotensin action on water absorption in the rat jejunum. J. Physiol. 192: 36. (Abstr.)

28. Cambridge, D., M. J. Davey, and R. Massingham. 1977. The pharmacology of antihypertensive drugs with special reference to vasodilators, $\alpha$-adrenergic blocking agents and prazosin. Med.J. Aust. 64(Suppl 1): 2-6.
29. Powell, D. W. and E. J. Tapper. 1979. Autonomic control of intestinal electrolyte transport. In Frontiers of Knowledge in the Diarrheal Diseases. H. D. Janowitz and D. B. Sachar, editors. Projects in Health, Inc.

30. Field, M. 1979. Intracellular mediators of secretion in the small intestine. In Mechanisms of Intestinal Secretion. H. J. Binder, editor. Alan R. Liss, Inc., New York. 83-91.

31. Kimbrough, H. M., E. D. Vaughan, Jr., R. M. Carey, and C. R. Ayers. 1977. Effect of Intrarenal angiotensin II blockade on renal function in conscious dogs. Circ. Res. 40: 174-177.

32. Carey, R. M., E. D. Vaughan, Jr., J. A. Ackerly, M. J Peach, and C. R. Ayers. 1978. The immediate pressor effect of saralasin in man. J. Clin. Endocrinol. Metab. 46: $36-43$.

33. Assaykeen, T. A., and W. F. Ganong. 1971. The sympathetic nervous system and renin secretion. In Frontiers in Neuroendocrinology. L. Martini and W. F. Ganong, editors. Oxford University Press, New York-Oxford. 67102.

34. Peach, M. J. 1971. Adrenal medullary stimulation induced by angiotensin I, angiotensin II and analogs. Circ. Res. 28(Suppl. II): 107-116.

35. Peach, M. J. 1977. Renin-angiotensin system: Biochemistry and mechanisms of action. Physiol. Rev. 57: 313-370.

36. Bengis, R. G., T. G. Coleman, D. B. Young, and R. E. McCaa. 1979. Long term blockade of angiotensin formation in various normotensive and hypertensive rat models using converting enzyme inhibitor (SQ 14, 225). Circ. Res. 43 (Suppl I): I-45-I-53.

37. Powell, D. W., and M. Field. 1980. Pharmacological approaches to treatment of secretory diarrhea. In Secretory Diarrhea. J. S. Fordtran and S. G. Shultz, editors. American Physiological Society, Bethesda, Md. 187-209.

38. Trachte, G. J., and A. M. Leffer. 1979. Beneficial action of a new angiotensin-converting enzyme inhibitor (SQ 14,225) in hemorrhagic shock in cats. Circ. Res. 43: 576-582.

39. Bolton, J. E., K. A. Munday, C. Murley, B. J. Parsons, and J. A. Poat. 1976. The relationship between plasma angiotensin II concentrations and fluid transport by rat jejunum in-vivo. J. Physiol. 254: 811. (Abstr.)

40. Freedlender, A. E., and T. L. Goodfriend. 1977. Angiotensin receptors and sodium transport in renal tubules. Fed. Proc. 36: 481. (Abstr.) 